\title{
DEVELOPMENTAL CHARACTERISTICS OF PRESCHOOL AGED GIRLS FROM DIFFERENT URBAN AREAS
}

\author{
Darko Stojanović $^{1}$, Nikola Stojanović ${ }^{1}$ and Ratomir Đurašković ${ }^{1}$ \\ ${ }^{1}$ Faculty of Sport and Physical Education, University of Niš, Serbia
}

Short scientific paper

\section{SUMMARY}

Human growth and development are under the influence of both genetic and environmental factors. Longitudinal and transversal dimensions of skeleton are, to a large extent, genetically determined contrary to circular dimensions, body weight and skin fold. The aim of this research was to determine developmental differences between the girls from Vranje and Užice. This research was conducted in kindergartens of Vranje and Užice. The sample comprised 136 girls, 72 of whom were 5 (+ eight months) years of age from Užice, and 64 of whom were 5 (+ seven months) years of age from Vranje. We used standardized instruments to measure the anthropometric characteristics, according to the methodology recommended by the International Biological Program (Weiner \& Lourie, 1981). The

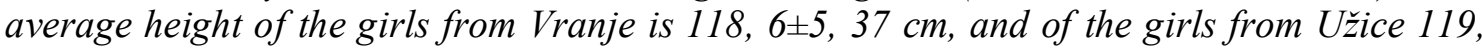
$4 \pm 5,46 \mathrm{~cm}$. The girls from Uzice were taller than those from Vranje, but the difference in height is not statistically significant. The results have shown that there is statistically significant difference in leg length. The average leg length of the girls from Vranje is $63,2 \pm 4,55 \mathrm{~cm}$, and those from Uzice $64,7 \pm 3,96 \mathrm{~cm}$. The girls from Vranje have greater pelvic width than the girls from Užice, which is statistically significant. We have not observed statistically significant differences concerning other measured anthropometric variables.

Key words: developmental characteristics, girls, preschool age, urban environment.

\section{INTRODUCTION}

The basic task of preschool institutions is to provide an optimum contribution to the physical growth and development of children, the development of their motor and functional abilities, as well as to provide the necessary conditions for living and being creative within a community (Bala, Popović \& Madić, 2005).

Through the study of morphological characteristics we obtain primary information on the human somatic status which is determined by anthropometric dimensions. The question is, under which circumstances are these dimensions additionally developed (for example, physical activity or other ecosocial factors. Anthropometric characteristics differ in terms of gender, age, and genetic-ecosocial conditions (Gajev, 2009).

The growth and development of children is greatly influenced by genetic and environmental factors of the surroundings in which they develop and grow. External factors are important for achieving the genetic maximum of a polygenetic growth pattern. The influence of external factors (the environment) at the preschool age is greater when compared to the subsequent periods of growth and development. Of the external factors, the social status of parents is of great influence for the optimum growth and development of the child. Spontaneous and organized forms of physical activity at the preschool age are important, both from a motor, but also cognitive and functional aspect of development. In this phase it is important for physical activity to be of the appropriate intensity, suited to the age and physical abilities of the child, both in terms of calendar and biological age (Đurašković, 2009). 
At this age the annual growth in terms height growth and other anthropometric indicators of children is not that pronounced, and so we could say that the child is in a relatively stable phase of growth and development (Đorđić, Bala, Popović \& Sabo, 2006). Physical growth and development to a certain extent can also depend on the environment in which they takes place Here we include whether rural or urban environments, higher and lower altitudes (Nikolić \& Paranosić 1980). Healthy life habits are formed during the preschool and young school age, and growth and development take place in relatively stable stages, unlike the pubescent phase. With the aim of the objective evaluation of growth and development, we rely on a method of standards used to compare the obtained anthropometric parameters with the same indicators of participants of the same age and gender (Mišigoj-Duraković, 2008). It is necessary to also take into consideration the fact that a child is not a "small man" and for that reason has its own growth pattern of morphological and functional-physiological characteristics. Information on the growth of children in terms of their height and body mass is often used to evaluate their health status and their BMI, as well as to evaluate the tempo of their growth and development (Božić-Krstić, Rakić \& Pavlica, 2003).

This research has as its aim to determine the differences in the anthropometric characteristics of preschool children from the urban environments of Vranje and Užice.

\section{METHODS}

The overall sample consisted of 136 girls, 72 of whom had an average age of 5 years and 8 months from Užice, and 64 participants with an average age of 5 years and 7 months from Vranje. All of the participants attended the same preschool and were healthy during the measuring of their anthropometric characteristics.

The evaluation of anthropometric characteristics included measures of longitudinal, transversal and circular dimensionality of the skeleton, as well as subcutaneous fatty tissue. The following measures were taken:

I - To evaluate the longitudinal dimensionality of the skeleton:

1. body height $(\mathrm{BH})$,

2. leg length (LL),

3. arm length (AL),

II - To evaluate the transversal dimensionality of the skeleton:

4. shoulder width (SW),

5. pelvic width $(\mathrm{PW})$,

6. hip width (HW),

III - To evaluate the circular dimensionality of the skeleton:

7. body mass (BM),

8. body mass index (BMI),

9. average thorax volume (ATV),

10. upper arm circumference (UAC),

11. lower leg circumference (LLC),

IV - To evaluate subcutaneous fatty tissue:

12. upper arm skin fold (UASF),

13. back skin fold (BSF) and

14. abdominal skin fold (ASF).

The measuring of all these morphological parameters was carried out in accordance with the International Biological Program (Weiner \& Lourie, 1981). 


\section{RESULTS}

Tables 1. and 2. show the descriptive statistical parameters of the preschool girls from Užice and Vranje. Following their analysis, based on the value of the arithmetic means and minimum and maximum score, we can conclude that the results of all the morphological measurements had normal distribution, except the back skin fold and abdominal skin fold for both sets of girls.

Table 1. The basic statistical parameters of the anthropometric characteristics of preschoolaged girls from Užice

\begin{tabular}{lccccc}
\hline Varijable & N & AM & MIN & MAX & SD \\
\hline AGE & 72 & 5.8 & 5.0 & 7.0 & 0.67 \\
\hline BH & 72 & 119.4 & 107.0 & 132.5 & 5.46 \\
LL & 72 & 64.7 & 56.0 & 73.5 & 3.96 \\
AL & 72 & 51.3 & 44.8 & 57.7 & 2.99 \\
\hline SW & 72 & 26.6 & 23.8 & 30.5 & 1.42 \\
PW & 72 & 19.1 & 16.0 & 23.0 & 1.39 \\
HW & 72 & 20.8 & 17.2 & 27.7 & 1.77 \\
\hline BM & 72 & 22.9 & 16.0 & 35.0 & 4.02 \\
BMI & 72 & 16.02 & 11.70 & 21.63 & 2.02 \\
ATV & 72 & 58.5 & 50.6 & 71.0 & 4.26 \\
UAC & 72 & 17.8 & 14.4 & 22.6 & 1.78 \\
LLC & 72 & 36.2 & 26.3 & 54.0 & 4.43 \\
\hline UASF & 72 & 12.1 & 6.2 & 21.2 & 3.64 \\
BSF & 72 & 7.5 & 3.6 & 19.0 & 3.60 \\
ASF & 72 & 8.0 & 3.0 & 23.4 & 4.70 \\
\hline
\end{tabular}

Legend: $\mathrm{N}$ - number of participants; AM - arithmetic means; MIN - minimum value; $\mathrm{MAX}$ - maximum value; $\mathrm{SD}$ - standard deviation.

Table 2. The basic statistical parameters of anthropometric characteristics of preschool girls from Vranje

\begin{tabular}{lccccc}
\hline Varijable & N & AM & MIN & MAX & SD \\
\hline AGE & 64 & 5.7 & 5.0 & 7.0 & 0.50 \\
\hline BH & 64 & 118.6 & 109.8 & 131.6 & 5.37 \\
LL & 64 & 63.3 & 52.2 & 73.5 & 4.54 \\
AL & 64 & 51.5 & 42.5 & 61.8 & 3.10 \\
\hline SW & 64 & 26.7 & 23.6 & 31.2 & 1.60 \\
PW & 64 & 19.6 & 16.9 & 22.9 & 1.42 \\
HW & 64 & 21.1 & 18.9 & 25.5 & 1.45 \\
\hline BM & 64 & 22.8 & 17.0 & 32.0 & 4.13 \\
BMI & 64 & 16.15 & 12.76 & 22.32 & 2.25 \\
ATV & 64 & 58.8 & 50.2 & 70.5 & 4.70 \\
UAC & 64 & 17.9 & 15.0 & 23.2 & 1.96 \\
LLC & 64 & 36.9 & 31.0 & 47.0 & 4.28 \\
\hline UASF & 64 & 12.8 & 6.0 & 20.6 & 3.92 \\
BSF & 64 & 8.3 & 3.0 & 19.4 & 3.92 \\
ASF & 64 & 9.2 & 3.0 & 24.0 & 4.69 \\
\hline Legend: N - the number of participants; AM - arithmetic means; MIN - \\
minimum value; MAX - maximum value; SD - standard deviation. \\
\hline
\end{tabular}

By analyzing the differences (Table 3) of the mean values of the anthropometric characteristics of preschool girls from Užice and Vranje, which belong to different urban environments, we can conclude that in all the measured characteristics there are no statistically significant differences, except for leg length, which is statistically significantly 
greater for the girls from Užice ( $\mathrm{p}=0.049)$, and pelvic width, which is statistically significantly greater than for the group of girls from Vranje $(\mathrm{p}=0.012)$. By studying the numeric differences between the female participants of these two urban environments, a difference can be noted. The girls from Užice had somewhat greater values for height and leg length, had narrow hips and pelvic bones, had somewhat smaller circular measurements and subcutaneous fatty tissue in comparison to the girls from Vranje. Based on these data, we can conclude that the girls from Užice were taller and have a gracile build (are the mesomorphic-ectomorphic type), and the girls from Vranje were somewhat shorter and had the characteristics of endomorphic build (according to Sheldon).

Table 3. The difference between the arithmetic means and anthropometric characteristics of preschool girls from Užice and Vranje

\begin{tabular}{|c|c|c|c|c|c|c|}
\hline \multirow[b]{2}{*}{ Varijable } & \multicolumn{2}{|c|}{ Preschool Užice } & \multicolumn{2}{|c|}{ Preschool Vranje } & \multirow{2}{*}{$\mathbf{t}$} & \multirow{2}{*}{$\mathbf{p}$} \\
\hline & $\mathbf{A M}$ & SD & $\mathbf{A M}$ & SD & & \\
\hline AGE & 5.8 & 0.67 & 5.7 & 0.56 & 1.634 & 0.104 \\
\hline BH & 119.4 & 5.46 & 118.6 & 5.37 & 0.874 & 0.383 \\
\hline $\mathbf{L L}$ & 64.7 & 3.96 & 63.2 & 4.55 & 1.984 & 0.049* \\
\hline $\mathbf{A L}$ & 51.3 & 2.99 & 51.4 & 2.81 & -0.081 & 0.935 \\
\hline SW & 26.6 & 1.42 & 26.7 & 1.56 & -0.250 & 0.802 \\
\hline PW & 19.1 & 1.39 & 19.7 & 1.41 & -2.524 & $0.012 *$ \\
\hline HW & 20.8 & 1.77 & 21.1 & 1.45 & -0.927 & 0.355 \\
\hline BM & 22.9 & 4.02 & 22.8 & 4.10 & 0.180 & 0.857 \\
\hline BMI & 16.02 & 2.02 & 16.18 & 2.37 & -0.414 & 0.679 \\
\hline ATV & 58.5 & 4.26 & 58.9 & 4.68 & -0.544 & 0.586 \\
\hline UAC & 17.8 & 1.78 & 17.9 & 1.94 & -0.445 & 0.656 \\
\hline $\mathbf{L L C}$ & 36.2 & 4.43 & 36.7 & 4.21 & -0.713 & 0.476 \\
\hline UASF & 12.1 & 3.64 & 12.7 & 3.91 & -0.969 & 0.333 \\
\hline BSF & 7.5 & 3.60 & 8.3 & 4.12 & -1.176 & 0.241 \\
\hline ASF & 8.0 & 4.70 & 9.2 & 5.01 & -1.405 & 0.162 \\
\hline
\end{tabular}

\section{DISCUSSION}

By analyzing the means (Table 1), the arm length $(51.3 \mathrm{~cm})$ of the preschool girls from Užice ranges within the normal values for that age, but their body height $(119.4 \mathrm{~cm})$ and leg length $(64.7 \mathrm{~cm})$ are somewhat greater than the norm (Gerver \& DE bruin, 1996) and the values recorded in studies which dealt with the development characteristics of girls of this age (Bala, 2009; Mišigoj-Duraković, 2008; Đurašković, 2009). In the case of transversal measurements, we can also conclude that they range within the values which are considered normal for this age, considering the values reported in previous studies. It is clear that there is a significant difference between our data and the values for pelvic width reported by Gerver \& DE bruin (1996), with the values reported in our study being somewhat greater. However, this can be considered the effect of acceleration over a period of almost twenty years. Body mass and the body mass index range within the normal values for the level of nourishment of girls this age, as do the circular measurements (thorax volume, upper arm volume and upper leg volume). The values of the subcutaneous fatty tissue are somewhat greater than those determined in the aforementioned studies, which leads us to the conclusion that girls aged 5 to 7 from Užice have a somewhat greater body height, but smaller percentage of muscle mass in relation to the body fat component, considering that their body mass index is within the normal range, and in accordance with the nourishment criterion (Cole, Bellizi, Flegal \& 
Deitz, 2000). By analyzing the means (Table 2), the body height $(119.4 \mathrm{~cm})$, arm length $(51.3$ $\mathrm{cm})$ and leg length $(64.7 \mathrm{~cm})$ of the preschool girls from Vranje range within the normal values for that age group (Gerver \& DE bruin, 1996) and the research results which dealt with the developmental characteristics of girls of this age group (Bala, 2004; Mišigoj-Duraković, 2008; Popović, 2008; Đurašković, 2009). In the case of transversal measurements, we can also conclude that they range within the normal values for that age, compared to the values reported in previous studies, except for the values of hip width $(21.1 \mathrm{~cm})$, which is somewhat greater than the normal value for that age. Body mass and the body mass index range within the normal values of the level of nourishment for girls this age, as do the circular measurements (thorax volume, upper arm and upper leg volume). The values of subcutaneous fatty tissue are slightly greater than those determined in the aforementioned studies, which leads us to the conclusion that girls aged 5 to 7 from Vranje have normal body height, but a reduced percentage of muscle mass in relation to the overall mass component, considering that their body mass index is within the normal, and in accordance with the nourishment criteria (Cole, Bellizi, Flegal i Deitz, 2000). The growth and development of humans is influenced by internal and external factors. Of all the internal factors, the genetic one has the greatest influence. However, this influence is not identical for all latent body dimensions. The longitudinal dimensionality of the skeleton is to the greatest extent under the influence of inherited genetic material, and it ranges from 85 to $98 \%$, depending on the author (Malacko, 1985; Kolarov, 2005; Đurašković, 2009). According to Nikolić \& Paranosić (1980) physical growth and development to a certain extent can also depend on the environment in which it is taking place, and this includes the rural and urban environment, higher and lower altitude levels, climatic conditions and so on.

The study we carried out included a sample which corresponded to the previous samples, and consisted of preschool children aged $5 \pm 1$, all from the urban environments of Užice (411 ma) and Vranje (480 ma), which can be found at approximately equal altitudes. It was determined that height and the analyzed longitudinal and transversal dimensions of the body are within the ranges of normal growth and development for the analyzed period of development (Gerver \& DE bruin, 1996; Mišigoj-Duraković, 2008), with the addition that the girls from Užice are somewhat taller and have longer legs in comparison to girls from Vranje, and that the latter group of girls had somewhat higher values for hip and pelvic width. These differences can probably be explained by the physical identity of the populations from western and easter Serbia, guided by the knowledge that western Serbia is an area of the predominantly dinarian type (according to Vladimir Dvorniković, as cited in Popović), while in eastern Serbia we find the slovene (nordic) anthropological type (according to Jovan Cvijić, as cited in Bogdanović). The dinarian anthropological type has the characteristics of high, gracile individuals, with a conspicuously longer lower body, while the slavic (nordic) type is characterized by shorter stature and a longer upper body part.

\section{CONCLUSION}

By comparing the anthropometric characteristics of preschool girls aged five to seven from two urban environments which can be found at the same altitude, but in different parts of Serbia, Užice in the western part and Vranje in the eastern part, we can conclude that the girls from western Serbia are somewhat taller, and have longer legs in comparison to the girls from the eastern part, which have a wider pelvis and hips. The girls from Užice belong to the mesomorphic-ectomorphic type, while the girls from Vranje are somewhat shorter and have the characteristics of the endomorphic build. 
This conclusion can be explained by the previous data collected on the different physical characteristics of the population of western and eastern Serbia, which confirm that the dinarian anthropological type is dominant in western Serbia, and the slavic (nordic) anthropological type is dominant in eastern Serbia. Under the assumption that the influence of the other internal and external factors on the growth and development of children was the same for both samples, we can conclude that the physical identity of certain anthropological types has a significant influence on the growth and development of children.

\section{REFERENCES}

Bala, G. (2004). Kvantitativne razlike osnovnih antropometrijskih karakteristika i motoričkih sposobnosti dečaka i devojčica u predškolskom uzrastu. Glasnik Antropološkog društva Jugoslavije, 39, 219-227.

Bala, G., Popović, B. \& Madić, D. (2005). Relationship between motor abilities and school rediness in preschool children. Kinesiologia Slovenica, 11(1), 5-12.

Bogdanović, M. Ljudske rase i njihova razvojna psihologija. Preuzeto 17.12.2014. godine sa: http://enlite.org/dinaric.pdf

Božić-Krstić, V., Rakić, R. \& Pavlica, T. (2003). Telesna visina i masa predškolske i malađe školske dece u Novom Sadu. Glasnik antropološkog društva Jugoslavije, 38, 91-100.

Cole, T.J., Bellizzi, M.C., Flegal, K.M. \& Dietz, W.H. (2000). Establishing a standard definition for child overweight and obesity worldwide: international survey. British Medical journal, 320, 1240-1243. https://doi.org/10.1136/bmj.320.7244.1240

PMid:10797032 PMCid:PMC27365

Đorđić, V., Bala, G., Popović, B. \& Sabo, E. (2006). Fizička aktivnost devojčica i dečaka predškolskog uzrasta. Novi Sad, (RS): Fakultet fizičke kulture.

Đurašković, R. (2009). Sportska medicina. Niš, (RS): M KOPS Centar.

Gajev, A. (2009). Fizička razvijenost i fizičke sposobnosti dece osnovnoškolskog uzrasta. Beograd (RS): Jugoslovenski pregled, Jugoslovneski zavod za sport.

Gerver, M.J.W. \& DE Bruin, R. (1996). Pedijatric Morphometrics. Utreht, (NL): Wetenschappelijke uitgeverij Bunge.

Kolarov, N. (2005). Dete i sport. Sportska medicina, 5(1): 22-26.

Malacko, J. (1985). Uticaj programiranog vežbanja na psihosomatski status dece za sport. Novi Sad, (RS): Fakultet fizičke kulture.

Mišigoj-Duraković, M. (2008). Kinantropologija. Zagreb, (RH): Tiskara Zelinda.

Nikolić, A. \& Paranosić, V. (1980). Selekcija u košarci. Beograd, (RS): „Partizan“.

Popović, B. (2008). Trend razvoja antropometrijskih karakteristika dece uzrasta 4-11 godina. Glasnik Antropološkog društva Srbije, 43, 455-465.

Popović, ¿́. Fizički indentitet. Preuzeto 17.12.2014. godine sa: http://www.koreni.net/modules.php?name=News\&file=print\&sid=2592

Weiner, J.S. \& Lourie, J.A. (1981). Practical Human Biology. New York, (USA): Academic Press.

Received: 20.05.2017. Accepted: 25.06.2017.

Corresponding author:

Stojanović Darko, PhD student

The Faculty of Sport and Physical Education, University of Niš

Nis, Serbia

E-mail: darko87_nish@hotmail.com

Mobile phone: +381666090005 